\title{
CPI Welcomes the Fall 2019 Special Issue: "Caribbean Pelau" with Carol Campbell, invited Guest Editor
}

Carol Campbell's Special Issue showcases the spectacular and dynamic growth of the visual, literary and performing arts in the Caribbean region. To develop her CPI Special Issue, entitled "Caribbean Pelau", Campbell casts her invitational net widely, reaching as far north as Toronto, Canada, into parts of the USA, through to Miami, and finally, south to capture some recent work in the twin-island republic of Trinidad and Tobago. Accordingly, the catchment pool of contributors to CPI's, Volume 11, No. 3, 2019, includes a number of Caribbean women and men, who through their academic, professional and community activities have contributed groundbreaking work nationally, regionally and in many cases, internationally.

With the inclusion of such a wide range of types of artistic and literary works, it is difficult to identify a few overarching themes, concepts and commonalities in this CPI Special Issue. However, by stepping back, and taking a global perspective, we note that a major commonality shared by all Caribbean territories, whether, as former British, French, Spanish, Portuguese, or Dutch colonies, is a shared history. Due to several hundred years of colonization by different western European powers, dating to Columbus' arrival in the late $15^{\text {th }}$ Century, the region has experienced the brutality of the enforced enslavement of millions of Africans who survived the forced transportation through the Middle Passage to arrive in the new world to become properties of European slavocracies. However, as some of the contributors indicate, the physical bodies of the enslaved men and women were in chains during slavery, but their minds, hearts, souls and spirits could not be constrained and controlled. Accordingly, in the Caribbean, African legacies of the forefathers and mothers are still reflected (visibly and invisibly), in aspects and elements of the languages, cultures, attitudes, behaviours and social relationships.

As importantly, the region has welcomed through the centuries, the voluntary and involuntary migrations of people from Western Europe, India, China, and the Middle East who have left their marks on the respective countries. The African Caribbean people (the largest proportion of the region's population), together with the descendants of people from the other counties, have resulted in the emergence of the Caribbean people, known for their indomitable spirits and active resistance to forms of systemic and structural oppression. The spirits of resiliency, the abilities to find ways to tease, disrupt and sometimes to erode and even sabotage the dominant culture's stranglehold is demonstrated explicitly and implicitly, in a number of the contributions.

In the big picture, the Caribbean has produced some exceptional men and women who include: three Nobel Prize recipients, namely, Derek Walcott, the poet and Sir Arthur Lewis, the economist in international development, both from St. Lucia. The third Nobel Prize recipient was Sir V. S. Naipaul (from Trinidad and Tobago originally), for his contributions to literature. During the past 50 to 60 years, the region has produced internationally noted academics, such as the historians, Elsa Goveia, from Guyana, Lucille Mathurin-Mair, from Jamaica, Eric Williams, a former Prime Minister of Trinidad and Tobago, and the UWI Professor Emeritus, Vice Chancellor, scholar and co-founder of the National Dance Theatre Company (NDTC) of Jamaica, Rex Nettleford. As importantly, there is Edward Baugh, from Jamaica, a respected literary figure and Professor Emeritus, University of the West Indies who has published some of Derek Walcott's poems, to name a few of the exceptional Caribbean individuals.

Cultural and Pedagogical Inquiry, Fall 2019, 11(3), pp. $i$-v

ISSN 1916-3460 @ 2019 University of Alberta

http://ejournals.library.ualberta.ca/index.php/cpi/index 
For this CPI issue, Carol Campbell has succeeded in garnering from across the English-speaking Caribbean, contributions from some of the established and emerging movers and shakers in the world of social justice in the arts and in humanistic education. The works included, from the visual arts, i.e. Paula Daley's cover and Donnette Zacca's closing image; to the poetry, specifically, by Charlotte Henay and Yasmin Glinton, and Dennis Conrad et al.; through to the essays and articles from Eugene Williams, Edward Baugh, Glenda-Rose Layne, and Meagan Sylvester. The written texts by Nicholeen Degrasse-Johnson and Christopher Walker, Alix Pierre, Lesley-Ann Noel et al., Jean Small, and Oneika Russell, include original illustrations which enhance the work. All contributions attest to the impressive nature of the issue.

In her Editorial, Carol Campbell describes her issue as a Caribbean Pelau, however, it is possible that a close reading of the respective works will reveal that the issue, indeed, comes alive to write, speak, paint, sing and dance with insights and perceptions, as well as, the distinctively, high levels of energy and rhythms associated with the Caribbean. Once more, a CPI issue demonstrates that the periphery, is creating, capturing and sustaining itself unapologetically, at the centre.

\section{Future CPI publications include the following:}

In Summer 2020 (Vol. 12, No. 1), Cecille DePass, Enid Lee, Sonia Aujla Bhullar and Alleson Mason, will produce a Special Issue: "I know why the caged bird sings" (Maya Angelou). To date, thanks mainly to Alleson Mason's successful invitational efforts to individuals across Canada, we have received an impressive number of national proposals. In addition, we have received a few sound international proposals. Even a few individuals have submitted their completed camera ready works. However, if any of CPI's readers have relevant work which fits the theme, and would like to submit it, please see the Call for Submissions in this issue. This international CPI issue will explore collective, familial and individual strategies of resistance and resiliency of immigrants from the south and racialized minorities who live in economically, developed countries.

In Fall 2020 (Vol. 12, No. 2), Nicholas Ng-A-Fook, with assistance from Carol Lee and Hembadoon Iyortyer Oguanobi, at the University of Ottawa, will produce an international issue entitled: "Living Stories of Migrancy: Exile, Unconditional Hospitality, and Transnational Citizenships". See the Call for Submissions in this issue. The proposed issue is timely, and likely to include some very thought provoking work.

\section{Under discussion:}

(i) In Summer 2021 or 2022, a team of Indigenous academics will produce an international Special Issue on Indigenous matters. The issue will be follow-up major issues in CPI, Vol. 10, No. 2, 2018. The Call for Submissions will be published in CPI, Vol. 12, No. 1, 2020.

(ii) In Fall 2021 or 2022, an international team will produce a Special Issue which explores the multiple roles, functions, challenges and triumphs of the literary, visual and performing arts in contemporary societies. Emphasis will be placed on explorations and 
analyses of educational contexts in which the arts promote and foster social justice, equity, peace, and the well-being and dignity for all of us. The Call for Submissions will be published in CPI, Vol. 12, No. 1, 2020.

\section{CPI's Book Reviews}

Working with the CPI Book Review Committee, Kathy Sitter, CPI Book Review Editor, presents three book reviews of recently published books. Individuals willing to review books for CPI should see the Call for Book Reviewers (CPI, Vol. 9, No. 2, 2017) and contact Kathleen Sitter, CPI Book Review Editor.

Invitations and caveats: As an independent, voluntary, academic online journal, hosted by the University of Alberta Libraries, CPI welcomes contributions which expand our conceptual and theoretical horizons, and demonstrate ways in which equity, fairness and justice are conceptualized and/or practiced in education (formal, non-formal and informal).

CPI welcomes proposals to develop special issues, and to create additional eBooks in the Legacy Series, introduced in Winter 2019.

Although CPI publishes some contributions which are critical of the existing status quo, it is committed to publishing works which portray hope for a better future for all and not for a few of us. As importantly, CPI promotes the vision of a fairer, more equitable and a just-world as documented in the UN Universal Declaration of Human Rights, and espoused and practised by for example, Martin Luther King Jr., Mahatma Gandhi, Paulo Freire, Kofi Anan, Desmond Tutu, Toni Morrison, Maya Angelou, bell hooks, Vandana Shiva, to name a few.

Contributions published in CPI, do not necessarily express the perspectives and considered opinions of the CPI Editorial Board, its founding editors, reviewers and production team.

\section{Reminders:}

(i) CPI invites its Editorial Board, readers and contributors to share information regarding, fairly recent research, publications and accomplishments.

(ii) CPI continues to welcome contributions from/by academics in the south and north in the fields of: literature, humanities, social sciences, arts, and of course, in education.

(iii) CPI requests that any future publication, exhibition, or performance of specific work published in the journal, kindly acknowledges its prior publication in CPI. 


\section{Arrivals and Departures:}

CPI welcomes and looks forward to Nicholas Ng A-Fook's and his team's major Special Issue: "Living Stories of Migrancy: Exile, Unconditional Hospitality and Transnational Citizenship", to be published in Fall 2020.

Enid Lee, anti-racist educator and Director of Enid Lee Consultants, is an invited co-editor, for CPI, Vol. 12, No. 1, 2020. Enid Lee continues to apply the anti-racist perspective first presented in her book: "Letters to Marcia: A Teachers' Guide to Anti-Racist Education" (1985), in a wide variety of educational settings in Canada and throughout the USA. Recently, for example, Enid Lee was a panelist and contributed the paper: "Designing Our Legacy, Passing the Baton", at the Inaugural Symposium, "Pathways to Educational Leadership", sponsored by 100 Accomplished Black Women in September, in Toronto, Ontario. Her next stop was in Reno Nevada. For the $27^{\text {th }}$ Annual Two-Way Bilingual Immersion Conference, Lee presented: "Checking and Changing Our Systems for Racial Equity in Bilingual Education”. On November 2nd, Enid Lee delivered the keynote address: "Marching with Martin and Beyond to Justice, Joy and Generosity", at the fundraising dinner, for the Resource Center for Nonviolence, in Santa Cruz, California. The final stop for 2019, will be in Nashville, Tennessee; Enid Lee will be the key facilitator, for the National Association for Education of Young Children's (NATEC) annual conference, which releases the Association's formal position concerning, "Advancing Equity in Early Childhood Education". In all her presentations, Enid has included some of the ideas, concepts and strategies from her comprehensive educational tool: "Checking and Changing my Systems for Equity”. For more information, visit Lee's website: www.enidlee.com.

Sarah Jane Moore at the University of New South Wales, Australia, is creating another thought provoking video with one of her original songs and some of her artwork, for inclusion in CPI Special Issue for Summer 2020.

Kim Koh, Cecille DePass and Sean Steel (2019) have published a timely book entitled: “Developing Teachers' Assessment Literacy: A Tapestry of Ideas and Inquiries" (Leiden \& Boston: Brill/Sense). By drawing on theoretical, conceptual, historical and comparative literature, as well as the authors' educational experiences in three former British colonies, the book explores significant aspects of assessment. The intent is to promote ways of developing preservice and in-service teachers' assessment literacy within different sociocultural and political contexts. As importantly, based on their respective educational backgrounds, academic experiences and applied fields of study, each author presents a critical response to the topic of assessment (a summary and extract from the book's back cover).

\section{Departures:}

Toni Morrison (1931-2019), distinguished novelist and scholar, was well loved in the USA and internationally, for her abilities to break silences and present the life world of African-Americans, mainly women. Dr. Morrison was the first African-American woman to be awarded the Nobel Prize in literature (1993). Her citation for the award from the Swedish Academy, stated that “...her novels characterized a visionary force and poetic import... [she] gives life to an essential aspect of African reality" (Google, New York Times Obituary, August 7, 2019). Toni Morrison's books include: The Bluest Eye, Sula, Song of Solomon, Beloved (which won the Pulitzer Prize, 
1988), and more recently, Home. In 2012, she received the President's Medal of Freedom from Barack Obama (Google).

Juanita Abernathy (1931-2019), was a renowned civil rights activist and leader. She was a key planner of the Montgomery bus boycott. Her activism continued despite, receiving death threats. When she passed away, Mrs. Abernathy was one of the few remaining US civil rights leaders who had worked closely, with Martin Luther King Jr. She was the wife of Rev. Ralph Abernathy, a stalwart leader of the civil rights movement. In 2015, Juanita Abernathy was awarded the Phoenix Award by the Congressional Black Caucus, USA (Google).

Francis Crowe (1919-2019), the stubbornly persistent peace activist in the USA who was known to always take the moral ground. Francis Crowe's conscience forced her to vocally protest against all forms of war, from the dropping of the first nuclear bomb on Hiroshima, Japan in 1945 by the US, to the Vietnamese war, to continuing for the rest of her life, to take an active part in civil disobedience actions and to protest against nuclear war and missile deployment (Google).

Elijah Cummings (1951-2019), the highly respected lawyer, politician and civil rights advocate, served as a Congressman in the US House of Representatives from 1996-2019. He chaired the Oversight Committee, one of three committees involved in the Trump-Ukraine impeachment inquiry. He was described as 'a champion of truth, justice and kindness'. At Cummings' funeral, former US President, Barack Obama, stated in his eulogy that, "[Elijah Cummings'] commitment to justice and the rights of others...never wavered" (Google and also the Guardian obituary, October 25, 2019).

We thank the Guest Editor, Contributors, international and national External Reviewers, the Senior Journal Manager and the Desktop Publisher, for their unstinting work, sometimes under very difficult circumstances, to produce CPI's 2019 Fall issue.

Perhaps, it is fitting to end this Editorial on a note of hope with two of Toni Morrison's quotes. Both quotes are applicable to Carol Campbell's CPI issue for Fall 2019:

"Freeing yourself was one thing, claiming ownership of that freed self was another" (Google).

"If there is a book that you want to read, but it hasn't been written yet, then you must write it" (Google).

Very best wishes for the northern hemisphere winter and the southern hemisphere summer.

Cecille DePass and Ali Abdi

CPI Editors and Founders

Cultural and Pedagogical Inquiry, Fall 2019, 11(3), pp. i-v

ISSN 1916-3460 () 2019 University of Alberta

http://ejournals.library.ualberta.ca/index.php/cpi/index 